\title{
The EU Maritime Regime and Challenges for Land- locked Developing States: Evidence from Ethiopia
}

Tessema Elias Shale *

\begin{abstract}
EU plays a dominant role in international maritime governance, and it has comprehensive maritime policies and strategies that have implications for third States. On the other hand, developing landlocked States (LLS) have the lowest bargaining power in the international maritime arena owing to their economic and geographic position. This article examines the implications of the EU maritime policy for developing LLS. After analysis of primary and secondary data as well as empirical evidence from Ethiopia, it is argued that the EU maritime governance such as its port State control regime and maritime market access regulations could possibly make international maritime trade through the EU waters as well as global maritime trade unaffordable for developing LLS. In view of the inherent challenges encountered by developing LLS and the economic interest of these States, it is submitted that there is a need to accord differential treatment schemes in the maritime field to these States at global and at the EU level.
\end{abstract}

\section{Key terms:}

EU Maritime Policy · Developing Landlocked States - UNCLOS · Port State Control · EU Maritime Regulations ·

DOI http://dx.doi.org/10.4314/mlr.v14i2.3

This article is licensed under a Creative Commons Attribution-

NonCommercial-NoDerivs (CC BY-NC-ND)

Received: (Version 2) 16 July 2020

Accepted: 28 December 2020

\section{Suggested citation:}

Tessema Elias Shale (2020), 'The EU Maritime Regime and Challenges for Land-locked Developing States: Evidence from Ethiopia,' 14 Mizan Law

Review 2: 239-275

* Tessema Elias Shale, Asst. Prof., Hawassa University, School of Law

Director, Hawassa University Free Legal Aid Service Center

Email: <tesemadararo@gmail.com>

ORCID: https://orcid.org/0000-0001-6187-675X

Various themes of this article were originally part of the author's LL.M thesis (2017), which are updated with supplementary elements. 


\section{Introduction}

More than $80 \%$ of the world trade is conducted by seas; and $90 \%$ of the volume of international trade in developing countries' is seaborne. ${ }^{1}$ The European Union (EU) transports $90 \%$ of its external trade and $40 \%$ of its internal trade by sea. ${ }^{2}$ EU ship owners control $40 \%$ of the global fleets with high competitive quality. ${ }^{3}$ Four of the top ten ship owning countries of the world are located in Europe. ${ }^{4}$ One third of global shipping has EU ports either as origin or destination. ${ }^{5}$ Moreover, EU ports alone entertain 3.5 billion tons of cargos and more than 400 million passengers per year. ${ }^{6}$ So, it can be said that the EU has a dominant share in the international shipping market as ship owning nations as well as coastal or port nations. Due to its dominant position and interests in global maritime market, the EU plays a dominant role in international maritime governance. ${ }^{7}$

\section{Frequently used acronyms}

ESLSE Ethiopia Shipping Lines and Logistic Service Enterprise

IMO International Maritime Organization

IMP Integrated Maritime Policy for European Union

LLS Land-locked States

UNCLOS United Nations Convention on Law of Sea

${ }^{1}$ United Nations Conference on Trade and Development (UNCTAD), Review of

Maritime Transport, UNCTAD Publication, UNCTAD/RMT/2015 (Geneva and New

York: 2015), 48 available at: http://unctad.org/en/PublicationsLibrary/rmt2015_en.pdf, (Last Visited on 8/27/2020).

2 The European Union, "Towards a future Maritime Policy for the Union: A European vision for the oceans and seas", Green Paper COM (2006) 275 final, 2006 Brussels

${ }^{3}$ Ibid.

${ }^{4}$ UNCTAD, Review of Maritime Transport, 47

${ }^{5}$ Oxford Economics, "The Economic Value of Shipping Industry", A Report for European Community Ship-owners Association (April 2014) available at: http://lsa.lt/images/articles/naudinga_info/2014-0401\%20Oxford\%20Economics\%20Shipping\%20value.pdf (Last Visited on 8/27/20)

${ }^{6}$ Ibid

${ }^{7}$ See for example, Commission of the European Communities, "Progress of the EU's Integrated Maritime Policy", Final Report from the Commission to the European Parliament (2012), the Council, the European Economic and Social Committee and the Committee of the Region. One of the objective of EU as reflected under this official report runs, "At global level, the EU has pushed for more ambition in the resolutions on oceans and the law of the Sea and on sustainable fisheries, promoting global membership of maritime governance instruments...." See also EU, 'Commission Communication on Strategic goals and recommendations for the EU's maritime transport policy until 2018 COM (2009)8 final, 2009, Brussels. Available at: http://eur-

lex.europa.eu/legalcontent/EN/TXT/PDF/?uri=CELEX:52009DC0008\&from=EN 
The EU strives to enhance a global playing field for its shipping industries, inter alia, through open maritime market, access to cargoes and free competition with third States. To this end, EU has passed several regulations. The EU's maritime market access strategy aims at enhancing competitiveness of its internal maritime market, ensuring development of open market worldwide and to "take the lead to promote alignment of its substantive competition law globally."

The EU places high emphasis on maritime safety, security and environmental protection. In this respect, the EU is determined to remove sub-standard vessels from its waters thereby advocating progressive advancement of the standards. In order to achieve this, the EU enforces the International Maritime Organization (IMO) rules and standards thereby transposing it into its laws. The EU also exercises the jurisdictional powers of its coastal and port States and adopts its own standards to foreign vessels operating in its waters or visiting its ports. This has raised an international law of sea issue of jurisdictional balance among port, coastal and flag States. In light of this, there is debate on the legitimacy of introducing unilateral regulations to international shipping. In this regard, the EU is known for the adoption and application of its regional regulations and standards for foreign vessels in its waters or visiting its ports.

It can thus be said that the EU's maritime governance can affect global operation of shipping business. Even though the EU's regulatory activation is appreciated for bringing an effective enforcement regime to the shipping business, it is also criticized for being a challenge to the uniform adoption and application of international shipping regulations. ${ }^{9}$ Particularly, it is imperative to examine its implications for developing landlocked States (LLS) due to their weak bargaining power in the international maritime arena owing to their economical and geographic position. This article

(Last visited August 17, 2010). One of the strategic goals stated that "the Commission will take the lead to promote alignment of substantive competition laws globally."

${ }^{8}$ Communication from the Commission to the European Parliament, the Council, the European Economic and Social Committee and the Committee of the Regions, "Strategic goals and recommendations for the EU's maritime transport policy until 2018', , (COM/2009/0008)final available at:

http://eur-lex.europa.eu/legal-content/en/ALL/?uri=CELEX\%3A52009DC0008

${ }^{9}$ See Philippe Boisson, "Development, impact and consequences of the EU maritime safety policy on maritime activities. A challenging time for the shipping industry", 1. available at http://www.sname.org/HigherLogic/System/DownloadDocumentFile.ashx?Document FileKey=247f1eb7-7d17-4a26-96f5-9d2903b6562f (Last visited on 9/12/2020). 
examines the implications of the EU maritime governance for developing LLS. Landlocked States from the developed world have different realities and hence are not included within the scope of the article. ${ }^{10}$

Relevant primary and secondary sources such as: EU acquis (the body of European Union Law), case laws, Ethiopian laws, international treaties, EU policy documents and review of scholarly literature are used in the study. Empirical data gathered through in-depth interview of experts and officials from Ethiopian Maritime Affairs Authority (EMAA) and Ethiopia Shipping Lines and Logistic Service Enterprise (ESLSE) have also been used.

The first section of the article discusses EU's Integrated Maritime Policy and highlights the organizational nature of the EU and the scope of its competence to represent Members States. The second section deals with the link between the EU's dominant position in international maritime arena and the coordination resulting from the policy and competence. This section provides general discussions on the global trends of extension of coastal and port States' sovereignty power with particular emphasis on the EU in light of international law, and possible implications for developing LLS.

Sections 3 and 4 highlight EU maritime regulations that have direct impact on third States. These sections focus on how some of these regulations can impact developing LLS. Particular focus is made on the EU Regulations on "Freedom to Provide Service"11 and "coordinated action to safeguard free access of ocean cargos." 12 It is very important to assess the existence of general right of access to sea for the LLS as engagement in shipping business cannot be realized without due recognition to the right of access to seas.

Sections 5 and 6 assess the need for access to the sea for LLS and the theoretical background for this right. Section 7 examines whether there is internationally recognized right of access to sea for the LLS by analyzing the international legal framework with particular attention to three main conventions, i.e., the 1921 Barcelona Convention, the 1965 New York Convention and Article 125 of the UNCLOS.

In Sections 8 and 9, the implications of the EU maritime policy for developing LLS is analyzed by taking empirical evidence from Ethiopia. Under these sections, the main challenges of maritime transport sector of

\footnotetext{
${ }^{10}$ LLS from developed world benefit from better infrastructure and logistic services, better bargaining position, small distance from sea coasts or ports and have regional arrangements for free access to seas.

${ }^{11}$ Regulation (EEC) No 4055 / 86

${ }^{12}$ Regulation (EEC) No 4058/86
} 
The EU Maritime Regime and Challenges for Land-locked Developing States... 243

Ethiopia are assessed. Challenges, inter alia, international maritime transport costs and tough international competition are identified. Whether EU maritime policy can contribute to the aggravation of these challenges is highlighted by analyzing empirical data from Ethiopia and analysis of the EU maritime regulations $v i s-\grave{a}$-vis international rules or standards. Ethiopia has been selected (in this section) among LLS because it has 56 years' experience in international shipping transport service, and it is party to several international treaties related to the issue.

\section{Overview of the EU's Maritime Policy and its Scope of Application}

European States are among the major maritime nations of the world. Seas and oceans are the backbone for Europe's economy. Before the European Union (EU) developed an integrated maritime policy, each Member State had its own compartmentalized policy on maritime governance. ${ }^{13}$ This fragmentation was said to have posed risk for sustainable use of maritime resources. ${ }^{14}$ Hence, in 2006, with the publication of the 'Green Paper' titled "Towards a Future Maritime Policy for the Union: A European Vision for the Oceans and Seas", a proposal was made to integrate the EU policies on seas and oceans. ${ }^{15}$ The document, among other things, emphasizes the economic potential of the EU maritime sector for Europeans and the EU's intention to regulate and lead sustainable maritime development agenda in an integrated manner. ${ }^{16}$ Following the Green Paper, the EU adopted 'Integrated Maritime Policy for European Union (IMP)' in 2007. The IMP is a comprehensive policy accompanied by a detailed action plan for implementation of the plan. As explained by Timo Koivurova ${ }^{17}$,

The term "IMP" is used ... to denote the following three documents: The Integrated Maritime Policy (CEC 2007a), adopted via a Communication

13 Jaun C. Suris-Reguiro et al (2013), 'Marine Economy: A proposal for its Definition in the European Union," Marine Policy 42:1.

${ }^{14}$ Ibid.

${ }^{15}$ Commission of the European Communities, "Towards a Future Maritime Policy for the Union: A European Vision for the Oceans and Seas" (Green Paper), Volume II, COM (2006) 275 Final, 7.6.2006, Brussels.

${ }^{16} \mathrm{Ibid}$, p. 4

17 Timo Koivurova (2012), Integrated Maritime Policy of the European Union: Challenges, Successes, and Lessons to Learn, Coastal Management, 40:2, 161-171, Available at http://dx.doi.org/10.1080/08920753.2012.652515 last accessed on 14.08.2020 (The source author's prescribed citation style). 
(the so-called Blue Book), its accompanying Action Plan (CEC 2007b) and the "environmental dimension" (CEC 2008b) of the IMP, the Marine Strategy Framework Directive (MSFD).

The IMP is meant to consolidate the EU's power and jurisdiction in maritime areas. ${ }^{18}$ This scenario seems to have served as a springboard for the EU's dominant position to influence international maritime affairs thereby consolidating powers that were scattered in individual member States. While the IMP has brought concrete benefit for European economy "by avoiding duplication of spending and efforts, and encouraging the sustainable development of maritime activities for member States," 19 it is also argued that it has negative implications for third States particularly, for developing LLS.

Indeed, it gives the EU power to substantially influence international legal frameworks and institutions (like IMO) thereby making international standards very tight and unaffordable for developing LLS. The latter have the lowest bargaining power in the international maritime arena. The policy paved the way for the EU to unilaterally adopt and implement tight regulations and standards to international shipping thereby making its coasts and ports unaffordable to small countries engaged the international shipping service. Moreover, the EU's aggressive moves can result in counter actions or balance measures from other major maritime nations or regional blocks. Such trends can be the expansion of restrictive control by coastal or port States'. In the context of such tension, developing LLS might inevitably be the primary victims.

Even though the scope of the article does not include detail analysis of the institutional nature of $\mathrm{EU}$ and its competence to represent member States, it is important to highlight these aspects. The first reason is to assess whether the EU has legal basis (either exclusively or concurrently with its member States) to deal with third States on matters related to maritime transport. Particularly, assessing the EU's external competence in maritime affairs is relevant for the article because it has an impact on third States including developing States that have interest in EU waters. ${ }^{20}$ Secondly, it is

${ }^{18}$ Id., 162

${ }^{19}$ EC, Directorate-General for Maritime Affairs and Fisheries, "Progress of the EU's Integrated Maritime Policy", Report from the Commission to the European Parliament, the Council, the European Economic and Social Committee and the Committee of the Regions, $\operatorname{COM}(2012) 491$.

${ }^{20}$ For example, EU port State control (at EU level) bounds member States uniformly to enforce at their ports the EU regulation. This in effect makes the 'port or convenience' option available for third States useless as all conditions and 
The EU Maritime Regime and Challenges for Land-locked Developing States... 245

claimed that the EU has influenced the international legal and enforcement framework in the maritime field. This dominant position is attributable to the power, experience and expertise housed in each Member State. These are directly linked with the organizational nature of EU and its competence to represent member States.

The organizational nature of the EU along with its competence to represent member States in maritime affairs has been unique and sometimes controversial. As Timo Koivurova explains: ${ }^{21}$

Even though the EU is acting like a federal State in many ways -in some policy areas in an even more integrated manner than federal entities- its ocean powers differ from those of federal States (while federal States may have constitutionally delegated many of their powers to their subunits in many policy areas, this does not usually apply to maritime areas, where the federal level exercises most powers affecting areas beyond the immediate coastal zone or territorial sea; this fundamental fact does not hold true for the EU, which, apart from having exclusive jurisdiction over much of fisheries, has only shared powers over many of the maritime policies).

Henrik Ringbom, describes the EU as "neither a conventional intergovernmental organization nor a State." Its power has been characterized as to be located between a sovereign State and an intergovernmental State. ${ }^{22}$ In some respects, the EU has an exclusive competence over the Member States. ${ }^{23}$ The Court of Justice of the European Union (CJEU) has clearly recognized this power. In Commission v. Council (1971), ${ }^{24}$ the CJEU held that:

... the Community, with a view to implementing a common policy envisaged by the Treaty, adopts provisions laying down common rules, whatever form these may take, the Member States no longer have the right, acting individually or even collectively, to undertake obligations with third countries which affect those rules. ... the Community alone is in a position to assume and carry out contractual obligations towards

requirements to be imposed on ships visiting all EU ports are similar. See also Henrik Ringbom, The EU Maritime Policy and International Law (Boston: Martinus Nijhoff Publishers, 2008), 203.

${ }^{21}$ Koivurova, Integrated Maritime Policy of the European Union, supra note 17, 161

${ }^{22}$ Ringbom, The EU Maritime Policy and International Law, supra note 20, 27

${ }^{23}$ Ibid , 57

${ }^{24}$ Commission V. Council (1971) ECR, Case no. 22/70, 263. See also detail analysis by Ringbom, The EU Maritime Policy and International Law, supra note 20, 57-70. 
third countries affecting the whole sphere of application of the community legal system ... to the extent to which Community rules are promulgated for the attainment of the objectives of the treaty, the Member States cannot, outside the framework of the Community institutions, assume obligations which might affect those rules or alter their scope.

This ruling shows that the EU has an exclusive external jurisdiction on areas affecting common policy defined by the EU including some aspects of maritime transport.

The Treaty on Functioning of European Union (TFEU) describes the EU competence in three categories -Exclusive competence, ${ }^{25}$ shared competence between EU and Member States, ${ }^{26}$ and competence to support, coordinate or supplement the actions of the member States. ${ }^{27}$ Except for "the conservation of marine biological resources under the common fisheries policy" which clearly falls under the EU exclusive jurisdiction, the Treaty does not expressly clarify the category of the EU's competence in the maritime field. ${ }^{28}$ Under article 4(3) of TEFU, there is a general duty of Member States to sincere cooperation. In Commission v. Greece (2009) -where Greece had submitted an independent proposal to the IMO-, the European Court of Justice ruled that Greece failed to fulfill its duty to sincere cooperation obligation. So, existing case laws and practice show that the EU has full competence to adopt and implement laws, regulations and policies for the attainment of common EU objectives which may include the maritime field.

\section{Implications of EU's Exercise of Port or Coastal State Jurisdiction}

A port State jurisdiction refers to the jurisdiction a State may exercise over foreign vessels visiting its port. ${ }^{29}$ In principle, according to the United Nations Convention on the Law of the Sea (UNCLOS) and Customary International Law, a flag State has principal jurisdiction over ships flying its

${ }^{25}$ See TFEU Article. 3. Under exclusive competence, only the EU may legislate and adopt legally binding acts and member States shall not do so unless authorized by the EU (See TFEU Article. 2 (1)).

${ }^{26}$ TEFU, Article.3.and Article 2(1). In the case of shared competence, the member States can act only if the EU has chosen not to act

${ }^{27}$ TEFU, Article. 6

${ }^{28}$ TEFU, Article. 4(d)

${ }^{29}$ Beven Morten (2013), 'Port State Jurisdiction in New Zealand: The Problem with Sellers', Wellington Law Review, vol. 44: 559 
flag. ${ }^{30}$ Its power ranges from safety standard of ships, manning, marine safety and security and seafarer's welfare, and adopting "laws and regulations for the prevention, reduction and control of pollution of the marine environment from vessels flying their flag or of their registry" and enforcement of the laws and regulations. ${ }^{31}$ The basic rationale behind making flag States a principal regulator of ships in international maritime law is to enhance the freedom of navigation without undue influence by coastal or port States. ${ }^{32}$ Port and coastal States' jurisdiction is limited to exceptional circumistances. ${ }^{33}$ However, the EU port State control regime seems to have taken this "exception as a principle." 34 Under UNCLOS, except for the enforcement of internationally agreed rules and standards, port States do not have the right to prescribe rules and requirements for foreign vessels. $^{35}$

The usual justification presented by port States including the EU for the increased controls is the failure of flag States to effectively control ships flying their flags. In fact, due to expansion of artificial flag States on the pretext of flags of convenience, the flag States tend not to effectively control ships flying their flags. However, there is a clear remedy for the failure under Article 94 (6) of UNCLOS which reads:

A State which has clear grounds to believe that proper jurisdiction and control with respect to a ship have not been exercised may report the facts to the flag State. Upon receiving such a report, the flag State shall investigate the matter and, if appropriate, take any action necessary to remedy the situation.

${ }^{30}$ Camille Goodman (2009), 'The Regime for Flag State Responsibility in International Fisheries Law: Effective Fact, Creative Fiction and Further Work Required.' See also UNCLOS Article. 94 and 217

${ }^{31}$ See UNCLOS, Articles. 94,211 (2), 217

${ }^{32}$ Ibid, Article. 91. In addition to the recognition of general international law principle that treats a ship as a floating territory of a flag State, enhancing freedom of navigation is the basic principle of the international law of the sea.

${ }^{33}$ Both prescription and enforcement of rules and requirements for a vessel principally rests under the power of the flag State (UNCLOS Article. 94 and 217 respectively). However, only part of the enforcement of internationally agreed rules and requirements that may go to a port or a coastal State jurisdiction.

34 The common way of interpreting laws is by considering exceptions narrowly. This principle seems to have been reversed in the case of the EU port State control regime.

35 See for example UNCLOS, Article. 218 and revised MARPOL Annex VI Regulation 15 
According to this provision, it is clear that there is no legal room for port States to substitute the flag States' duty and what port States can do in the case of such failure on the part of the flag State. Another justfication made by the port States including the EU for their extended exercise of prescriptive jurisdiction is based on the claim that "a State generally does not have a legal right to access another State's port". ${ }^{36}$ In fact, this position is not without challenge at least for three reasons.

First, without a right access to ports, the principle of freedom of navigation, which is enshrined in international law, would be meaningless from a shipping perspective. ${ }^{37}$ In Nicaragua v. USA (1986), the International Court of Justice (ICJ) extended the right to innocent passage in the territorial sea zone to passage to and from internal water to access ports. ${ }^{38}$ The ICJ rendered this decision based on customary international law that obliges a State "not to interrupt peaceful maritime commerce" and article 18(b) of UNCLOS. ${ }^{39}$ The court interpreting article 18(b) of UNCLOS noted:

... it is true that in order to enjoy access to ports, foreign vessels possess a customary right of innocent passage in territorial waters for the purposes of entering or leaving internal waters; Article 18, paragraph I (b), of the United Nations Convention on the Law of the Sea of 10 December 1982, does no more than codify customary international law on this point. ${ }^{40}$

The right of access to internal waters, which is extended by the court, is not different from the right of access to ports from perspective of sovereignty right of port States. ${ }^{41}$ Hence, according to this judgment, it can be said that port States cannot arbitrarily deny foreign vessels -engaged in a peaceful maritime commerce- access to their ports or internal waters. However, the right to access to ports can be denied if ships that claim the

${ }^{36}$ Henrik Ringbom (2006), The EU's Exercise of Port and Coastal State Jurisdiction, Scandinavian Institute of Maritime Law, Yearbook. Henrik Ringbom and other European writers hold that port States do have a full "...right to deny ships access, or make that access dependent on the fulfi lment of certain conditions.»

${ }^{37}$ See UNCLOS Articles 17, 125, 148, 69, 38, 137 and 87. In order for land-locked States to transit, trade and enjoy the freedom of high sea (res communis), right to access territorial sea including access to ports of transit States is inevitable.

${ }^{38}$ In Nicaragua V. USA (1986), I.C.J. 14, para. 213, p.101. See also detail explanations by Bernardo Sepulveda Amor, The International Court of Justice and the Law of the Sea, 2012, p.8 available at http://www.corteidh.or.cr/tablas/r29686.pdf (Last accessed on $9 / 08 / 2020$ ).

${ }^{39}$ Ibid

${ }^{40}$ Nicaragua v. USA, Id., para 214, p. 101

${ }^{41}$ See the UNCLOS Article. 2(1) cum Article. 18 (b) 
access fail to fulfill requirements or conditions set by the port or flag states. Article 2 of the 1923 Convention on the International Regime of Marine Ports provides for a quid pro quo or reciprocity for the access; and if member States to this convention fail to accord reciprocal obligation, it may also be a ground for the denial of the access. Although application of this convention is limited to the member States and even if the rule has not acquired the status of customary international law, it may show a trend of international law.

Secondly, in order for landlocked States (LLS) to exercise their rights under international law of the sea, it is logical that they must have a right to access ports or there must be justifiable cause for the denial.$^{42}$ In this respect article 131 of UNCLOS provides that "[s] hips flying the flag of land-locked States shall enjoy treatment equal to that accorded to other foreign ships in maritime ports." Thirdly, even though ports are under the exclusive jurisdiction of Sovereign States, the right to deny access to the port or impose unreasonably strict requirements to deny access cannot be justified under UNCLOS. ${ }^{43}$ Had there been the intention to allow port States to deny access to foreign vessels, it would have been clearly provided for.

Access to ports is closely related to use of the seas and hence, the prerogatives of the Sovereignty right of a port State over its port should somehow be understood as compromised by the State by virtue of signing the Convention. ${ }^{44}$ Given the historical and theoretical foundation of States, it seems absurd to apply, as some writers do, ${ }^{45}$ solid territoriality or extra-

${ }^{42}$ UNCLOS, Article. 125, 148 and 38(1). See also The 1965 New York Convention 1965 On Transit Trade of Land Locked States. Most of the EU members are also members to this convention and bound to give "to ships flying the flag of that State (Land Locked) treatment equal to that accorded to their own ships, or to the ships of any other States, as regards access to seaports and the use of such ports..." (Preamble of the Convention)

${ }^{43}$ Article 217 of the UNCLOS states the power of a flag State to prohibit a vessel flying its flag or registry, the Convention does not give the same power to a port State under Article 218.

${ }^{44}$ See preamble of the UNCLOS. Even if the Convention recognizes sovereignty of member States, fairness, cooperation, equity and efficient utilization of seas and oceans resources are core principles of UNCLOS that should also be dealt with.

${ }^{45}$ See, for example, Joanne Scott (2014), "Extraterritoriality and Territorial Extension in EU Law," American Journal of Comparative Law 62, 1: 87-125, Nelson F. Coelho (2015), "Extraterritoriality from Port: EU's Approach to Jurisdiction over Ship-source Pollution," SYbIL 19: 269-284, See also Cedric Ryngaert and Henrik Ringbom 
territoriality sovereignty principles to sovereignty rights related with use of seas. Moreover, according to principles of interpretation of treaties provided in the Vienna Convention, good faith, purpose and object of the treaties shall be taken into consideration. ${ }^{46}$

One of the core purposes of the UNCLOS as provided at the beginning of the preamble is, "... desire to settle, in a spirit of mutual understanding and cooperation, all issues relating to the law of the sea and aware of the historic significance of this Convention as an important contribution to the maintenance of peace, justice and progress for all peoples of the world." This presupposes that State parties to the Convention must be considerate and cooperative in the use of sea related rights including sovereignty rights over their ports. So, there is little or no legal ground for coastal or port States to arbitrarily deny access or to set unjustifiable preconditions/standards against foreign vessles engaged in peaceful commerce. Prescribing a standard by a port State exceeding international standards would likely be unjustifiable and against the principle of freedom of navigation.

With regard to the possible implications of the EU's growing prescriptive port States jursdiction or controls for developing LLS, it is an issue of concern because the EU has united interests as coastal and port States as well as union of flag States. So, If the EU continues its execcessive port or coastal State jurisdictional schemes by setting its own different standards to foreign vessles, there is a high probability that other major port or coastal States may exercise countermeasures for port control in their capacity as port States or as regional entities. The probability seems inevitable because international trade, including shipping is highly determined by competitive or bargaining position of the actors. This can also be inferred from the comment made by the International Chamber of Commerce and International Shipping Federation on the EU's Strategic Goal until 2018:-

...we believe the Commission should think very carefully before proposing any adjustment of the current balance between flag States and coastal States rights. Other coastal States around the world could potentially use any new entitlement to override current flag State rights for motives unconnected with safety and environmental protection,

(2016), 'Introduction: Port State Jurisdiction: Challenges and Potential,' The

International Journal of Marine and Coastal Law 31: 379-394

${ }^{46}$ See, Vienna Convention on the Law of Treaties (1969), Article. 31. 
The EU Maritime Regime and Challenges for Land-locked Developing States... 251

especially where evolving geo-political circumstances may lead to new perspectives. $^{47}$

There have already been several other regional integrations for the port State control and there are some individual powerful maritime States that have different port State control schemes. ${ }^{48}$ If major port or coastal States or regional blocks unnecessarily expand their port or coastal State powers as EU has done, there would be severe implications on developing LLS. For example, if a certain port State takes an excessive control against another port State's ships flying its flag, then that State may counteract or retaliate by using its power as a port State on its own port by prescribing and enforcing strict requirements. ${ }^{49}$ This may happen due to the fact that international maritime trade is, inter alia, dependent upon the bargaining position of the actors; and the bargaining position of States is determined by economic, diplomatic and geo-political positions of the States. But developing LLS cannot do this simply because they do not have ports or sea coasts or have the lowest bargaining position.

There is no preferential treatment or longer compliance period scheme available in the EU system for least developed LLS. So, the EU port State control system might result in ousting least developed nations, which cannot meet the standards or requirements, from using EU ports. As indicated earlier, EU's enhanced port State control may induce more port States controls from other major port or coastal States which, in effect, will adversely affect the interest of developing LLS.

${ }^{47}$ International Chamber of Commerce and the International Shipping Federation Comment on 'Strategic goal and Recommendations for the EU's Maritime Transport Policy until 2018

48 For example, regional integrations like: Tokyo Memorandum of Understanding (MoU) on Port State Control (for Asia-Pacific States), Latin America MoU on port State control, Caribbean MoU on port State control, Port State Control in Mediterranean region, MoU for the Black Sea, Abudja MoU on port State control (for west Africa), Riyadh MoU on port State control for Gulf region, and at individual State level US Coast Guard and possibly other powerful port States may have its own scheme for port State control.

${ }^{49}$ One of the key rationales for the integrated port State control including EU PSC is competition. 


\section{Objectives of the EU Maritime Regulations and their Enforcement Framework}

A regulation under the EU legal system is a legislation which has general application and automatic binding effect in all member States. ${ }^{50}$ Unlike EU directives which basically need to be transposed by the national legislator of a member State, EU regulations are binding regardless of the transposing act as explained as follows:-

Regulations are of general application, binding in their entirety and directly applicable. They must be complied with fully by those to whom they apply (private persons, Member States, Union institutions). Regulations are directly applicable in all the Member States as soon as they enter into force (on the date stipulated or, failing this, on the twentieth day following their publication in the Official Journal of the European Union) and do not need to be transposed into national law. They are designed to ensure the uniform application of Union law in all the Member States. Regulations supersede national laws incompatible with their substantive provisions. ${ }^{51}$

EU maritime market access regulations are aimed at enhancing competitiveness of internal maritime market and ensuring development of open market worldwide. ${ }^{52}$ The EU has regulated the maritime market access in three dimensions: -Freedom to provide service, unfair pricing and free access to ocean trades.

The EU's internal maritime market access strategy is geared towards strengthening capacity of EU shipping industry so as sustain its 'dominance'

${ }^{50}$ See Article. 288 of Treaty on Functioning of European Union (TFEU) which reads:

"... A regulation shall have general application. It shall be binding in its entirety and directly applicable in all Member States."

${ }^{51}$ Sources and Scope of European Union Law , available at http://www.europarl.europa.eu/ftu/pdf/en/FTU_1.2.1.pdf (Last visited on 9/08/2020)

${ }^{52}$ See for example, EU, 'Progress of the EU's Integrated Maritime Policy', Final Report from the Commission to the European Parliament, the Council, the European Economic and Social Committee and the Committee of the Regions, 2012. One of the objectives of EU as reflected under this official report reads: "At global level, the EU has pushed for more ambition in the Resolutions on Oceans and the Law of the Sea and on Sustainable Fisheries, promoting global membership of maritime governance instruments...". See also EU, "Commission Communication on Strategic goals and recommendations for the EU's maritime transport policy until 2018 COM (2009)8 final, 2009, Brussels. (Available at:

http://eur-lex.europa.eu/legalcontent/EN/TXT/PDF/?uri=CELEX:52009DC0008\&from=EN), last visited August 17, 2020. One of the strategic goals Stated that "the Commission will take the lead to promote alignment of substantive competition laws globally". 
The EU Maritime Regime and Challenges for Land-locked Developing States... 253

in the global market. One of the main issues addressed by the $2009 \mathrm{EU}$ strategic goal was 'EU Maritime Space without Barrier'. ${ }^{3}$ The focus was made on EU short shipping, cabotage and competition in internal market. But the long term strategy -as can be seen from the EU strategy- is internationalization of maritime law and practice from EU perspectives. This can be seen from the position boldly provided under the strategic document. It says, 'the Commission will take the lead to promote alignment of substantive competition law globally'. ${ }^{4}$ So, it is possible to say that the EU's exercise at home has usually something to do with global application. This can also be seen from the EU's strategic interest in membership of International Maritime Organization (IMO) which reads, "... formalizing the EU co-ordination mechanism and granting formal observer status, if not full membership, to the EU at IMO.," 55

The basic theme of this section is not the EU's 'indirect' policy objective and its implication. It rather focuses on the direct regulations that affect the interest of developing land-locked countries. There are three EU regulations which have direct effect on third countries. These are: Regulation 4057/86 (unfair pricing) ${ }^{56}$-relating to 'dumped freight rates by shipping companies of non-EU States', 'Regulation (EEC) No 4055/86 ${ }^{57}$-dealing with freedom to provide service, and 'Regulation (EEC) No 4058/86 -concerning coordinated action to safeguard free access to cargoes in ocean trades. ${ }^{58}$

The regulation (EEC) No. 4057/86 does not have significant immediate effect on the least developed nations for obvious reason that these States do not have capacity to dump goods and services yet. Hence, the focus is made on the latter two regulations.

\section{The EU Regulations on Freedom to Provide Service, Free Access to Ocean Cargoes and Countervailing Actions}

Regulations (EEC) No 4058/86 and Regulation (EEC) No 4055/86 are basically intended to act against restrictions imposed by third countries that EU believes negatively affect the community shipping industry. The

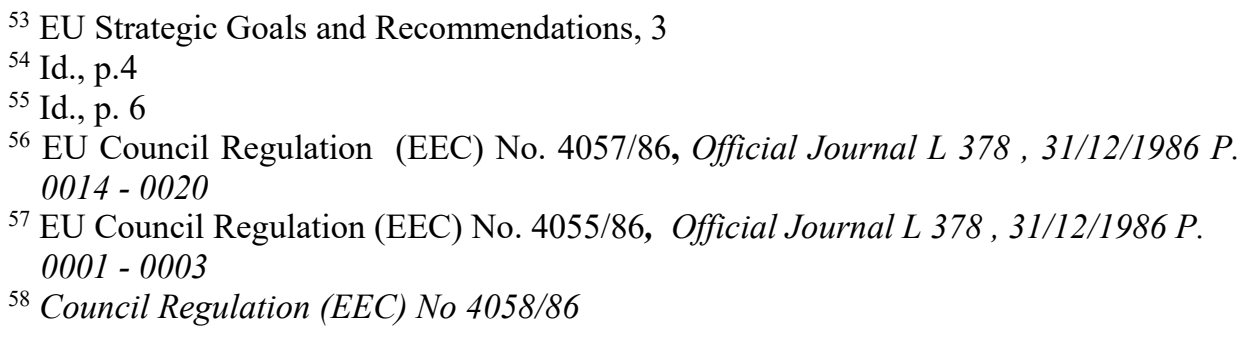


Regulation (EEC) No 4058/86 applies to nationals of member States regardless of whether they are established inside or outside the Community. ${ }^{59}$ As explained in the legislative summary, the Regulation "applies when action by a non-Community country or by its agents restricts free access to the transport of liner cargoes, bulk cargoes or other cargoes by shipping companies of member States or by ships registered in a member State. ${ }^{\circ 0}$ It provides for counter measures in the form of "coordinated action by the community following a request made by a Member State to the Commission. Such action might include diplomatic representation to non-Community countries and countermeasures directed at the shipping companies concerned". ${ }^{61}$

The aim of both Regulations is to enhance a free playing field for EU shipping industries by avoiding protectionism and restrictions from third States. ${ }^{62}$ However, they fail to take at least two important things into consideration. First, the regulation seems to have aimed at creating internationally free market without taking into consideration different realities of third States. However, states are at different stages of liberalizing their markets including their maritime service market. Service sectors in general and maritime sector in particular have not yet been liberalized in most developing countries. ${ }^{63}$

Secondly, the regulation failed to take the concern of small countries into consideration. It is true that EU has shipping industries with high quality and experience capable of competing globally. But before the EU industries reached this stage, they had been protected by their respective States. Even at present, the EU has maintained a state aid scheme for maritime transport. On the other hand, shipping industries from third developing countries cannot compete globally unless they are protected either by way of subsidy or cargos reservation systems or otherwise. Even worse, the regulations may subject developing LLS that reserve cargoes to national shipping industry or otherwise protect the industry based on special needs. These countries have very infant shipping industries and transit related costs are very high. Unless

${ }^{59}$ Rosa Greaves (1992), 'EC Maritime Transport Policy and Regulations’, Duke Journal of Comparative and International Law, Vol. 3:119-145

${ }^{60}$ Summary of EU legislations available at: http://eur-lex.europa.eu/legalcontent/EN/TXT/?uri=URISERV:124064 (Last visited on 18 August. 2020).

${ }^{61}$ Ibid

62 See Rosa Greaves, supra note 59, p. 130.

${ }^{63}$ For example, almost all service sectors including shipping industry in Ethiopia are operated by government. Most of African States have not yet liberalized its service sector. 
there is some kind of protection, they cannot compete with the EU industries. For example, Ethiopian shipping company's survival in the international shipping service is only due to subsidy from the State including reservation of imports to the company. ${ }^{64}$

Thus, unless the EU revisits its regulations by focusing on the EU equivalent third competitor States and unless it devises some kind of special or differential treatments to developing countries, the general approach (which may subject even the latter states to its countervailing measures) obviously have negative implications for these States. The worst impact would be inevitable for developing LLS that have the lowest bargaining power in global maritime market due to transit related challenges and economic capacity related problems.

\section{The Need for Access to the Sea for LLS and Challenges}

An overview of theoretical foundations and international legal frameworks (in this section and the section below) can enable us to assess implications of the EU maritime governance on developing LLS. To this end, it is very important to assess existence of general right of access to sea for the LLS. This is because we cannot talk of engagement of the LLS in shipping business without having internationally recognized right of access to seas.

A land-locked State is a State with no direct sea-coast. ${ }^{65}$ At present, there are forty-four land-locked States (LLS) which constitute approximately $22 \%$ of the States in the world. ${ }^{66}$ There are several developing LLS that are

${ }^{64}$ Interview with Ato Mekonnen Abera, director of Ethiopia Maritime Affairs Authority, June 4, 2017.

${ }^{65}$ Kishor Uprety (2006), "The Transit Regime for Land-Locked States: International Law and Development Perspectives", Law, Justice and Development Series No.34771 (2006):4. See also UNCLOS, Article. 124 (1) (a). The UNCLOS defines the LLS as 'a State which has no sea-coast.'

66 See Land Locked States available at https://www.thoughtco.com/landlockedcountries-1435421, Updated on August 8, 2020 , last accessed on August 19, 2020 Botswana, Burundi, Burkina Faso, Central African Republic, Chad, Ethiopia, Lesotho, Malawi, Mali, Niger, Rwanda, South Sudan, Swaziland, Uganda, Zambia, and Zimbabwe are the 16 LLS in Africa. Andorra, Austria, Belarus, Czech Republic, Hungary, Liechtenstein, Luxembourg, Macedonia, Moldova, San Marino, Serbia, Slovakia, Switzerland, and Vatican City are the 14 LLS in Europe. Afghanistan, Armenia, Azerbaijan, Bhutan, Laos, Kazakhstan, Kyrgyzstan, Mongolia, Nepal, Tajikistan, Turkmenistan, and Uzbekistan are the 12 LLS in Asia. Bolivia and Paraguay are the two LLS in South America. 
engaged in the shipping industry. ${ }^{67}$ Most of these States are the least developed. ${ }^{68}$ Several studies have identified transit related challenges that are faced by LLDC (Land-locked developing countries). For example, the study conducted under the World Bank by Kishor Uprety has summarized the challenges as follows:

... The international trade of these countries is dependent on the transittransport infrastructures and services along the routes through their transit neighbors, over which they have little control. Furthermore, the ability of the transit countries to improve, from their own resources, transittransport infrastructures and services in the ports and along the transit corridors is very limited because many of them are themselves developing countries... Transport costs (which include storage costs along the transit routes, insurance costs, costs due to extra documentation, and so forth) are in many cases quite significant because the facilities available are inadequate... ${ }^{69}$

Likewise, Uperty states the severe implications of being landlocked "because production, input use, consumption, and exportation are greatly influenced by the cost and reliability of transport to and from the outside world." He also states that "the majority of LLS are among the poorest countries of the world" and notes that "the absence of seacoast and their distance and isolation from international markets aggravate their economic situation and constitute the main reason for their underdevelopment". ${ }^{70}$

Another study conducted by the United Nations Conference of Trade and Development (UNCTAD) states that distance, travel time and cost (transit related problems) had been the main challenges for land-locked developing countries. ${ }^{71}$ Michael Faye has identified transit related challenges of landlocked developing States in dimensions relating to: dependence on sound political relations with transit States, dependence on neighbors' peace and

${ }^{67}$ For example; Ethiopia, Azerbaijan, Bolivia, Laos, Mongolia, Slovenia, Paraguay, Moldova are some of the developing LLS that have merchant vessel fleets. This, however, does not mean that LLS that do not have merchant vessel fleets do not have interest in engaging in the blue economy.

${ }^{68}$ Michael L. Faye, John W. McArthur, Jeffrey D. Sachs \& Thomas Snow (2004), 'The Challenges Facing Landlocked Developing Countries,' Journal of Human Development. Vol.5, No. 1: pp. 31-32. According to this source, nine out of twelve from LLS are also least developed States with the lowest human development indices.

${ }^{69}$ Uprety, Transit Regime for Landlocked States, supra note 65, p. 19.

${ }^{70}$ Ibid

${ }^{71}$ UNCTAD (2013), "Securing Reliable Access to Maritime Transport for Land locked Countries," Review of Maritime Transport, New York and Geneva 
The EU Maritime Regime and Challenges for Land-locked Developing States... 257 stability, and dependence on administrative practices of the transit States. ${ }^{72}$ It is already common knowledge that the main cause for underdevelopment in the land-locked developing States is directly linked with access to seas.

\section{The Theoretical Foundations}

\subsection{Freedom of transit}

There are two diverging views that represent those who consider States as duty bound to grant the right of transit to another State suffering from an unfavorable geographic position, and those who believe that such right depends upon the consent of the State granting the transit. ${ }^{73}$ Supporters of the former view argue that subjecting the transit right to a sovereign State's consent is absurd. According to this view, economic interdependence of States justifies the importance of juridical basis for recognizing the transit rights. ${ }^{74}$ Lauterpacht, as cited in Uprety, holds that "... States may legitimately claim 'the right of transit' under two fundamental conditions. First, the State claiming the right of transit must be capable of proving the merits and necessity of the right. Second, the exercise of the right must not cause disturbance or prejudice to the transit State (littoral State)". ${ }^{75}$ In fact, 'necessity' in the case of the LLS seems so apparent and hence it can be held that, according to this view, the LLS can claim right of transit when such right does not cause disturbance or prejudice to the coastal State.

On the other hand, opponents of this view state that the right to transit is subject to the consent of sovereign littoral States. As cited in Uprety, "leading international lawyers like McNair and Hyde believe that the transit right of LLS is not a principle recognized by international law but rather a right governed by agreements concluded with coastal States". ${ }^{76}$ Coastal States usually stick on their sovereign right to deny the transit freedom of LLS. As Mipazi Sinjela notes:

The major obstacle to development of a guaranteed right of access to the sea for land-locked countries has been the claim of territorial sovereignty by coastal States. These nations have consistently argued that principles of State sovereignty allow them to approve or disallow all transit through

72 Faye et al, The Challenges Facing Landlocked Developing Countries, supra note 68, p. 31

${ }^{73}$ Uprety, Transit Regime for Landlocked States, supra note 65, p. 28

74 Ibid

${ }^{75}$ Ibid, 29

${ }^{76}$ Ibid, 28 
their territories. Their position is that rights of access for land-locked countries are not properly resolved through a single international rule, but are instead a matter for bilateral or regional agreements. Countries of transit argue that sovereign jurisdiction over all activities within their territories includes the prerogative of denying the traffic of land-locked countries as a matter of security ${ }^{77}$

However, this view does not have acceptance from LLS as it subjects their right to political will of the transit States. ${ }^{78}$

\subsection{Free access and the principle of freedom of the seas}

This theory opposes the idea of exclusive use of oceans by a State against the use right of another State. It is built on the premise that the oceans particularly high seas fall under res communis -common for all navigators of international community. Mpazi Sinjela associates 'the principle of freedom of high sea' with 'principles of natural law' ${ }^{79}$ As Sinjela noted:

The claims of land-locked States were originally founded on principles of natural law. It was argued that the right of free transit was conferred on every land-locked country by its very sovereignty a necessary corollary to accepted notions of freedom of the high seas. This view maintained that, because the oceans are open to all nations, littoral and land-locked alike, the latter must be entitled to free transit in exercise of their equal rights within the res communis. ${ }^{80}$

According to this principle, in order to enjoy rights and freedom of high seas, the LLS must have right to pass through land, port infrastructure and territorial water of coastal States.

${ }^{77}$ Mpazi Sinjela (1982), 'Freedom of Transit and the Right of Access for Land-Locked States: The Evolution of Principle of Law' Georgia Journal of International and Comparative Law, Vol.12, No.1:35

78 Endalcachew Bayeh (2015), "The Rights of Land-Locked States under the International Law: The Role of Bilateral/Multilateral Agreements," Journal of Social Sciences. Vol. 4, No. 2: 27-30. Available at doi: 10.11648/j.ss.20150402.12. As Bayeh states, “... If they are not in a smooth relation, the transit States may not be willing to negotiate and thereby put impediments on the land-locked States' free transit."

${ }^{79}$ Mpazi Sinjela, 'Freedom of Transit and the Right of Access for Land-Locked States,' supra note 77, p. 32.

${ }^{80}$ Ibid 
The EU Maritime Regime and Challenges for Land-locked Developing States... 259

\section{3 Compensating for geographical inequalities}

This view emanated from the spirit of the law of the sea which gives due attention to cooperation and mutual understanding among State parties. ${ }^{81}$ Professor Rene-Gean Dupuy considers the law of the sea as a 'situationalist' law that takes particular situation of a single State into account. ${ }^{82}$ Kishor Uprety links this view, among other things, with the UN obligation to create "...conditions of stability and well-being, which are necessary for peaceful and friendly relations among nations". ${ }^{83}$ The right of access to sea in this respect is particularly linked with economic development needs of developing LLS.

Article 25 of the UN Charter obliges the international community to "... pay special attention to the particular needs and problems of the least developed among the developing countries, of land-locked developing countries. ..." It is also linked with the principle adopted by UNCTAD in the 1965 New York Convention which provides for "the cognition of right to every LLS to free access to the sea constitutes a principle indispensable for the expansion of international trade and economic development." ${ }^{" 84}$ In short, this view justifies the recognition of right of access to sea for LLS in general and developing LLS particular based on the principle of compensating for geographic and economic imbalances.

\subsection{Theory of international servitude.}

An international servitude is a limitation on territorial sovereignty right of a State called 'servient State' in favor of permanent use the territory by another State called 'dominant State'. ${ }^{85}$ It is derived from the Roman private

${ }^{81}$ The first paragraph of UNCLOS preamble which reads: “ “.. desire to settle, in a spirit of mutual understanding and cooperation, all issues relating to the law of the sea and aware of the historic significance of this Convention as an important contribution to the maintenance of peace, justice and progress for all peoples of the world."

82 René-Jean Dupuy (1974), The Law of the Sea: Current Problems (Oceana Publications). See also Uprety, Transit Regime for Landlocked States, supra note 65, p. 36.

${ }^{83}$ Uprety, Transit Regime for Landlocked States, supra note 65, p. 36. See also UN Charter, Article 55

${ }^{84}$ Uprety, Ibid. See also Principle I in the preamble of 1965 Convention on Transit Trade of Land-Locked States (New York Convention).

${ }^{85}$ See also explanations by Uprety, Transit Regime for Landlocked States, 31-33. 
law concept of a limited right of ownership of a property. ${ }^{86}$ Sinjela illustrates the concept and its relationship with the right of access to sea as follows:

If A's land were located in such a way that it was necessary to cross B's land before he could enjoy his own land, A was said to have a natural servitude across B's property. From this it may be argued that land-locked States have a similar servitude to traverse neighboring States, a logical and necessary extension of the sovereignty they exercise over their own territory ${ }^{87}$

However, it is controversial as to whether this private law concept, by analogy, applies to public international law. ${ }^{88}$ Proponents of right of access to sea as an international servitude argue that LLS can claim this right against coastal State based on the fact of their geographic position. ${ }^{89}$ Meanwhile, the opponents of this view counter argue that the theory of international servitude compromises the sovereign right of transit States. ${ }^{90}$ They also hold that it is totally improper to use such private law concept in public law. ${ }^{91}$ However, there is a general international law that prohibits "a State from taking any measure likely to modify the natural course of a waterway that passes through several States." 92 Some writers like, Uprety link this with the existence of right of access to sea on the ground of international servitude. ${ }^{93}$

\section{International Legal Frameworks}

As highlighted above, there have been strong theoretical bases on the right of access to sea for LLS in general and developing LLS in particular. Against these theoretical backgrounds, it is argued that there have been no strong international rules that adequately secure this right for the LLS. It is also said that international law of the sea tends to focus more on the expansion of coastal States' territorial sovereignty over seas thereby diminishing interests of landlocked and geographically disadvantaged

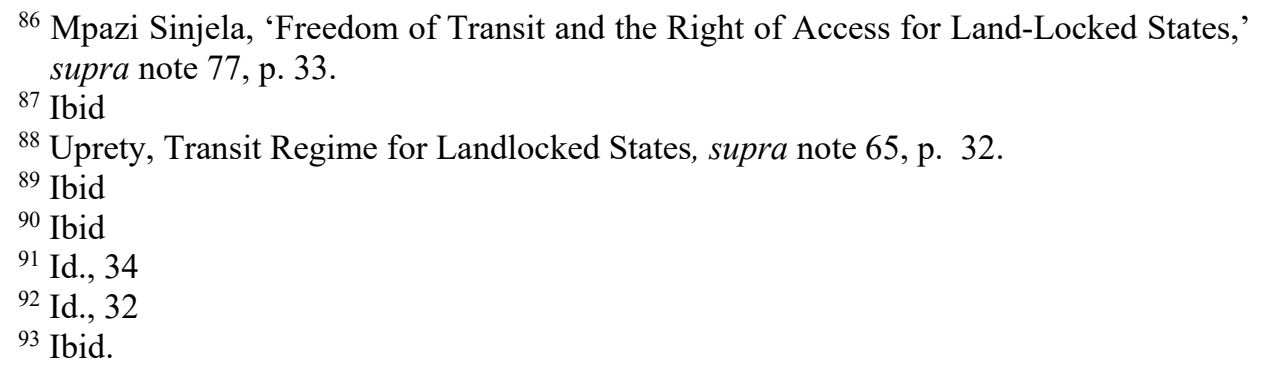


The EU Maritime Regime and Challenges for Land-locked Developing States... 261

States. ${ }^{94}$ The following discussion focuses on three main conventions that directly deal with the right of access to sea by the LLS. ${ }^{95}$

\subsection{The 1921 Barcelona Convention}

The Barcelona Convention is the pioneer convention in recognizing the freedom of transit. Particularly, article 2 of the Convention obliges States parties to facilitate the freedom of transit. However, the Member States do not have obligation to grant the freedom of transit to non-member States. The States parties also have the right to prevent the freedom of transit of passengers and goods prohibited in the territory of the States when the interest of the public, animals and plants interests so requires. ${ }^{96}$ So, it can be said that the Convention was aimed at balancing the recognition of the freedom vis-à-vis sovereignty interests of transit States.

However, this Convention has been criticized for its failure to offer strong and all inclusive legal bases on freedom of transit for LLS. As Mpazi Sinjela states "[a]lthough the Barcelona Conference provided a promising start for securing an internationally recognized right of transit, from the land-locked States' point of view, several deficiencies were evident in its scope and coverage." 97 In this regard he indicated deficiencies in (i) its

94 Helmut Tuerk (2015), 'Landlocked and Geographically Disadvantaged States,' In Oxford Handbook, eds. Donald Rothwell et al (Oxford Handbook Online: Oxford University Press,) p. 327. Tuerk explains the tendency of the international law of sea in favor of coastal States as follows:

A major shift thus occurred towards more national authority over maritime areas, leading to a diminution of the extent of the high seas and an attenuation of its freedoms, which has been called a transition from a 'law of movement' to a 'law of territory and appropriation'. This development directly affected the landlocked States as well as other States in a less favourable geographical position with respect to the seas and their resources, which would subsequently call themselves 'geographically disadvantaged States'. These two groups of countries came to realize that they would have little or nothing to gain from an extension of sovereign rights and jurisdiction over vast, valuable maritime areas. On the contrary, this trend placed them in an increasingly disadvantageous position with respect to maritime uses, as they were facing the loss of rights they had hitherto enjoyed either in practice or at least theoretically.

${ }^{95}$ In fact there are several other conventions like, GATT, the 1958 Convention on High Sea and other UN resolutions that directly or indirectly touch up on the right of transit for LLS. However, this study only focuses on: The 1921 Barcelona Convention, the 1965 New York Convention and the 1982 UNCLOS.

${ }^{96}$ See, the 1921 Barcelona Convention of Freedom of Transit, Article. 5

${ }^{97}$ Mpazi Sinjela, "Freedom of Transit and the Right of Access for Land-Locked States," supra note 77, p. 36. 
failure to declare the universal application of the right of transit, (ii) restriction of its scope to railway and waterway transport, and (iii) "the great prominence it accorded transit problems of land-locked countries in Europe, thereby failing to take sufficient account of the distinct position of States in the new world." 98

\subsection{The 1965 Convention on Transit Trade of Land-locked States}

The 1965 Convention on Transit Trade of Land-locked States (New York Convention) is the first convention that attempted to recognize the "right" 99 of LLS of free access to sea. It sets various principles in its preamble. Principle I states that the "recognition of the right of each land-locked State of free access to the sea is an essential principle for the expansion of international trade and economic development". According to Principle VII of the Convention, "[t]he facilities and special rights accorded to land-locked countries in view of their special geographical position are excluded from the operation of the most-favoured-nation clause."

Moreover, article 2 of the Convention provides for the freedom of transit and prohibits any discrimination based on "origin, departure, entry, exit or destination or on any circumstances relating to the ownership of the goods or the ownership, place of registration or flag of vessels, land vehicles or other means of transport used." The Convention also prohibits imposition of custom duty on goods in transit. ${ }^{100}$

In light of the above principles and rules, it can be said that the New York Convention recognized the right of LLS to access seas. However, the Convention indirectly renders these rights superfluous and ineffective by making the rights subject to the consent of coastal States or by employing a quid pro quo system to the access. It is to be noted that five of the eight principles provided under the preamble of the Convention, directly or indirectly, subject the right in question to the consent of coastal States or reciprocal obligation of the LLS. Particularly, the Convention provides for pre-conditions such as 'common agreement' 101 and 'reciprocity' 102 in

\footnotetext{
${ }^{98}$ Ibid

${ }^{99}$ Unlike the 1921 Barcelona Convention which deals only with 'Freedom', the New York Convention, deals with the "right" of free access.

${ }^{100}$ See New York Convention, Principle IV and Article. 3

${ }^{101}$ See New York Convention Article. 2(2) and the Principle III. According to this provision, in order the LLS enjoy the freedom of transit, it has to secure consent from the coastal States.

102 Ibid, Principle IV clearly provides that the LLS owe reciprocal obligation to coastal States in order to claim the right of access to sea via the coastal States.
} 
The EU Maritime Regime and Challenges for Land-locked Developing States... 263

addition to common public interest exceptions. ${ }^{103}$ These requirements incapacitate the practical application of the right of LLS to access sea.

\subsection{The 1982 UNCLOS}

The 1982 UNCLOS was, inter alia, the result of several conferences and Conventions. Particularly, three preceding conferences ${ }^{104}$ and four consequent conventions ${ }^{105}$ had a direct contribution to the contents of the Convention. Moreover, customary international law, international courts and arbitration tribunals, States practices and opinions of authors were also said to be core contributors to the contents of the 1982 UNCLOS. ${ }^{106}$

The 1982 UNCLOS is the first instrument that comprehensively regulates all parts of oceans' spaces, uses and resources in a single document. ${ }^{107}$ Hence, it is often regarded as 'Constitution for Oceans'. ${ }^{108} 168$ States including the EU are parties to the UNCLOS among which 28 are from LLS. ${ }^{109}$ Currently, there are 44 LLS and sixteen States from LLS have not yet been members to the Convention. Out of the 28 LLS, 20 members are from developing countries. ${ }^{110}$ One of the core aims of the Convention was to

103 The New York Convention, Article. 11 and 12

${ }^{104}$ The three UN Conferences preceding the 1982 UNCLOS are: the 1958 First UN Conference on the Law of Sea (UNCLOS I), the 1960 Second UN Conference on Law of Sea (UNCLOS II) and The 1973-1982 third UN Conference on Law of sea (UNCLOS III)

105 The four conventions preceding the 1982 UNCLOS are: the 1958 Convention on the Territorial Sea and the Contiguous Zone, the 1958 Convention on the High Seas, the 1958 Convention on Fishing and Conservation of Living Resources and the 1958 Convention on the Continental Shelf.

${ }^{106}$ Detail analysis of historical development of the 1982 UNCLOS was rightly made by Tullio Treves, 'Historical Development of the Law of the Sea,' In The Oxford Handbook of the Law of the Sea, eds. Rothwell et al (2015)

107 See Helmut Tuerk (2015), "Forgotten Rights? Landlocked States and the Law of the Sea," In Contemporary Developments in International Law Essays in Honour of Budislav Vukas, eds. Wolfrum and et al (Boston: Martinus Nijhoff Publishers) p. 337

108 Ibid.

${ }^{109}$ United Nations, "Chronological list of ratifications of, accessions and successions to the Convention and the Related Agreements," Division for Oceans Affairs and the Law of the Sea, available at http://www.un.org/depts/los/reference_files/chronological_lists_of_ratifications.htm , Last updated 23 may 2020, Last Accessed on 20 June $20 \overline{20}$.

${ }^{110}$ Developing LLS parties to the UNCLOS are; Chad, Lesotho, Lao People's Democratic Republic, Malawi, Mali, Mongolia, Nepal, Niger, Paraguay, Republic of 
strike a balance between the rights or claims of coastal States and the freedoms of seas enjoyed by all other coastal or landlocked States. ${ }^{111}$

The preamble of the Convention recognizes special interests and needs of developing States including LLS. ${ }^{12}$ There are also few articles in the Convention which provide for rights of LLS and preferential treatment for developing countries. Particularly, under Part X of the Convention, articles 124-132 directly address the 'right' of access to and from the sea and freedom of transit. Article 125(1) provides for LLS' right of access to and from the sea and freedom of transit through territory of transit states by using all means of transport. In this regard, the UNCLOS avoids quid pro quo system that was adopted in the New York Convention.

Article 127 prohibits imposition of taxes, custom duty or other charges on traffic in transit with the exception of charges levied for specific services. Similarly, it provides that the LLS shall not be discriminated in terms of taxes or other charges levied on 'the means of transport in transit' they may use. The UNCLOS also provides for the possibility of agreement between LLS and transit States so that the transit States could grant greater transit rights than the Convention does. ${ }^{113}$ To this effect, the Convention excludes such agreement from the application of the most-favoured-nation clause. ${ }^{114}$ In addition, it provides that "Ships flying the flag of land-locked States shall enjoy treatment equal to that accorded to other foreign ships in maritime ports." 115

Apart from the provision under Part X, there are several other provisions that deal with rights of LLS. For example, article 17 provides for the right of LLS to innocent passage in territorial zones of coastal States. Article 18 (1)(b) of the Convention extends the right of innocent passage to "proceeding to or from internal waters or a call at such roadstead or port facility." Moreover, subject to some limitations and exceptions referred therein, Article 69 of the UNCLOS grants LLS 'a right' to participate 'on an equitable basis' in the exploration and exploitation of the living resources of EEZs of coastal States of the same sub-region or region. According to article

Moldova, Swaziland, The former Yugoslav Republic of Macedonia, Uganda, Zambia, Zimbabwe, Armenia, Azerbaijan, Bolivia, Botswana and Burkina Faso,

${ }^{111}$ Helmut Tuerk (2016), 'Forgotten Rights? Landlocked States and the Law of the Sea,' In: R. Wolfrum,. M. Seršić and T.M. Šošić (eds.), Contemporary Developments in International Law, 338. See also paragraph four preamble of the UNCLOS.

112 See The UNCLOS, Preamble par. 6

113 The UNCLOS, Article. 132.

${ }^{114}$ Id., Article. 126

${ }^{115}$ Id., Article 131 
The EU Maritime Regime and Challenges for Land-locked Developing States... 265

87 of the Convention, high seas are open for all States, whether coastal or landlocked and article 90 provides for right of LLS to navigate ships flying their flags on the high sea

Article 125 of the UNCLOS is the main provision that deals with the 'right' of access to sea for LLS. However, whether it automatically grants the right of free access to and from the sea to the LLS has been controversial. Uprety argues that, "Article 125 does not grant any new rights to LLS. ... This article constitutes, indeed, a clear recognition of the principle. In practice, however, the modalities called for in paragraphs (2) and (3) must involve substantial qualifications". 116 Tuerk partly shares the above interpretation stating that "the right of access is made contingent upon bilateral, sub-regional, or regional agreements between the landlocked States and transit States, laying down the terms and modalities for exercising freedom of transit." 117 But Tuerk partly departs from Uprety's position by arguing that such preconditions of the provision were made to "strike a balance between the interests of landlocked States on one hand and those of transit States on the other, (and the provision) can be considered a significant achievement by the landlocked countries." 118

Sioussouras argued that in order to activate the right provided under article 125 of the Convention, "preliminary agreement stage -pactum de contrahendo or pactum de negotiando" between the LLS and transit States is needed. ${ }^{119}$ But Sioussouras does not deny that the transit States are duty bound to give consent to the agreement. However, there are writers who believe that article 125 of UNCLOS automatically grants the right of free access to and from sea irrespective of the consent of transit States:

This article (Article 125 of the UNCLOS) does four key effects. First, it guarantees the right of free access to and from the sea to landlocked states. Second, it also guarantees to them freedom of transit without any prerequisite if this freedom is to be exercised in relation to the right of free access to and from the sea. Third, it does not require a bilateral treaty with the transit state to be able to exercise the right of free access and freedom of transit. Only the derailed provisions of a technical character regarding the terms and modalities provisions of a technical character

\footnotetext{
${ }^{116}$ Uprety, Transit Regime for Landlocked States, supra note 65, p. 87

117 Tuerk, Landlocked and Geographically Disadvantaged States, supra note 94, p. 335

118 Ibid

119 Petros Sioussouras (2001), "The Formation of Customary Right in the International Law of the Sea,' Revue hellenique de droit international, Vol. 54, Issue No. 1: pp. 299-317
} 
regarding the terms and modalities for exercising freedom of transit have to be agreed upon with the transit state. However, the actual right to exercise this freedom is itself no longer dependent on a bilateral agreement with the transit state, fourth, breaking from the Barcelona tradition, it eliminates the requirement of reciprocity. ${ }^{120}$

According to the above interpretation, article 125(2) refers only to technical aspects dealing with how the right of access to and from the sea is implemented. Otherwise this sub article was not meant to set precondition for the access right itself.

In Turkey v. Iraq (1925), the Permanent Court of International Justice opined that, "if the wording of the treaty provision is not clear, in choosing between several admissible interpretations, the one which involves the minimum of obligations for the parties should be adopted." Moreover, Article 31 of the Vienna Convention on Law of Treaties states, "A treaty shall be interpreted in good faith in accordance with the ordinary meaning to be given to the terms of the treaty in their context and in the light of its object and purpose". As long as good faith and context are concerned, it is not reasonably expected from States Parties to UNCLOS to unfairly subject the right of access to consent of transit States.

Furthermore, the use of 'shall' in article 125, sub-articles (1) and (2), of the UNCLOS makes the provisions mandatory. Hence, by applying 'ordinary meaning' interpretation provided by the Article 31 of the Vienna Convention, it can be concluded that the LLS have the right of access to and from the sea, and coastal States are duty bound to agree on modalities and terms of how this right be exercised. If a coastal State and LLS fail to agree on the terms and modalities, the most probable way out could be resorting to available dispute settlement mechanisms.

To sum up, there is internationally recognized right of access to sea for LLS. And hence, there is little or no legal ground for coastal or port States to arbitrarily deny access or provide unjustifiable preconditions/standards for the access of their ports against foreign vessles engaged in peaceful commerce. Prescribing a standard by a port State exceeding international standard, as the EU does, would likely be unjustifiable and against the principle of freedom of navigation.

${ }^{120}$ Ramesh Kumar Rana (2010), "Right of access of land-locked state to the sea by the example of bilateral agreement between land-locked state- Nepal and port state India" (Master's Thesis, University of Tromsø Faculty of Law), p. 12 


\section{Overview of the Challenges for Ethiopia's Maritime Service Sector}

Ethiopia has become a landlocked State since May 1991 when Eritrea was separated from the country and became an independent State. Ethiopia was one of the major maritime nations in the horn of Africa before it lost its outlet to the Red Sea. The country started shipping business in 1964 with a fleet of three State owned ships. Even after being landlocked, Ethiopia has not stopped its engagement in international maritime commerce. Rather, it has continued engaging in the maritime business thereby making the port of Djibouti as a main outlet to the sea through a bilateral agreement. ${ }^{121}$

A State owned company, Ethiopian Shipping Lines and Logistics Service Enterprise (ESLSE), ${ }^{122}$ is operating international shipping business with eleven owned vessels ${ }^{123}$ and by using slot chartering of vessels from major global carriers such as MAERSK, ALP and MSC. All vessels that are owned and run by the ESLSE are registered and fly Ethiopian national flag. The ESLSE is the only company in the country that renders internal, coastal and international maritime transport services.

121 Ethiopia and Djibouti signed and ratified a bilateral agreement in 2002 on port utilization which gave Ethiopia, inter alia, the right to permanent utilization of the Port Djibouti. According to the 2013 World Bank Report, 93\% of Ethiopian imports and exports were carried out via the port Djibouti and $84 \%$ of the Port's traffic is in transit to and from Ethiopia. Further details can be accessed from, WB, 'Transport and Logistics in Djibouti: Contribution to Job Creation and Economic Diversification,' Final Report No. 75145, Middle Ease ad Northern African Region Transport Unit, February 2013.

122 The ESLSE was established by the Ethiopian Council of Minister Regulation, Regulation No.255/2011. The ESLSE was established by the merger of the former three public enterprises that have until 2011 been operating separately; namely, Ethiopian Shipping Lines S.C, Maritime and Transit Services Enterprise and Dry Port Enterprise. ESLSE is entrusted with duties, inter alia, to render coastal and international maritime and internal water transport services, to give multi-modal transport services and provide logistics services. Further detail is available at the ESLSE's Company profile, at:

http://www.ethiopianshippinglines.com.et/companyprofile, last visited on 02 August 2020.

${ }^{123}$ Names of the eleven vessels owned and operated by ESLSE are: Finfine, Hawassa, Bahirdar, Assosa, Harar, Mekele, Samera, Gambella, Jigjiga, Gibe and Abay Wonz. The names of the first nine vessels correspond to names of capital cities of both the federal and regional States of Ethiopia while the names of the last two vessels correspond to the two rivers that are serving as major sources of hydroelectric power in the country. 
Ethiopia is a member of IMO and has signed and ratified the 1982 UNCLOS. ${ }^{124}$ It has acceded to several other international and regional conventions related to maritime sector. ${ }^{125}$ Ethiopia is also a member of International Oceanographic Commission (IOC). ${ }^{126}$ These partly show the country's efforts to participate in international maritime regulations and governance with a view to secure its interest.

However, some of the memberships like membership to MARPOL, seem to be unreasonable. MARPOL is an International Convention for the Prevention of Pollution from Ships. Ships flagged under all parties to the Convention are required to meet standards set by the Convention regardless of the parties' special circumstances. It is to be noted that one of the core principles embodied under international climate conventions, i.e., 'Common but differentiated responsibilities and respective capabilities' (CBBDRC) is not recognized or given effect under the MARPOL Convention.

Under this Convention, developing States in general and landlocked developing States (in particular that have little contribution to marine pollution) are put under the same basket with developed maritime nations that have substantial contribution to global air pollution including the marine pollution. Specially, MARPOL Annex VI, which deals with Prevention of Air Pollution from Ships, has progressively been getting stricter from time to time through tacit acceptance amendment procedures. ${ }^{127}$ In the tacit

${ }^{124}$ Ethiopia joined IMO on 3 July 1975 and signed the UNCLOS on 10 December 1982. Ratifications of some international conventions the country signed including MARPOL and the UNCLOS have not deposited in their respective depositories yet.

${ }^{125}$ For example, Ethiopia acceded the 1966 International Convention on Load Lines , the 1972 Convention on the International Regulations for Preventing Collusions at Sea (as amended), the International Convention for the Safety of Life at Sea as amended and its Protocol of 1978 (SOLAS), International Convention on the prevention of Pollution from Ships 1973/78 ( MARPOL) International Convention on Standards of Training, Certification and Watch keeping for Seafarers, 1978 as amended ( STCW), International Convention on Civil Liability for Bunker Oil Pollution Damage (BUNKER, 2001), International Convention on Liability and Compensation for Damage in Connection with the Carriage of Hazardous and Noxious Substances by Sea (1996), International Convention on the Control of Harmful Anti-fouling Systems on Ships (2001), The 1988 Convention for the Suppression of Unlawful Acts Against the Safety of Maritime Navigation, International Convention on Tonnage Measurement of Ships, 1969 and The Revised African Maritime Transport Charter

${ }^{126} \mathrm{IOC}$ is a UN specialized in ocean science and services.

${ }^{127}$ For example, The MARPOL annex VI was adopted in1997 and entered into force in 2005. In 2008, substantial revision was made thereby making more significant limit on sulfur content a fuel oil used by ships which entered into force on July 1, 2010. 
The EU Maritime Regime and Challenges for Land-locked Developing States... 269

acceptance procedure, an amendment to a convention is deemed to have been accepted if a State party does not oppose the amendment within a timelimit provided in the convention. This clearly impedes developing States to amend technical rules under annexes including annexes of the MARPOL Convention.

The EU has been one of the major driving forces for the progressive tightening of the IMO's regulations either by implementing them in its water ahead of timelines set by the IMO or by using informal coordination mechanisms. ${ }^{128}$ In fact, the main reasons of the EU measures are insufficiency and slow move of existing IMO rules on the one hand, and disastrous accidents that have occurred in the EU waters on the other hand. ${ }^{129}$

However, developing countries in general and developing LLS (that have already been trapped with transit related costs and challenges, in particular) could not easily afford these moves. Indeed, they need more time for implementation of these rules or they need to be accorded differential treatment. Hence, it seems unreasonable for landlocked developing States like Ethiopia to sign this kind of instrument that does not take special circumstances of this group of nations into consideration.

As Anene Kejela (an International Cooperation Expert in Ethiopian Maritime Affairs Authority) noted, it was a big mistake to ratify the MARPOL Convention. ${ }^{130}$ Mekonnen Abera, Director of Ethiopia Maritime Affairs Authority (EMAA), in this regard stated, "we did not really notice or saw it in this way when we signed this particular Convention; however, we signed or acceded to international maritime related conventions including our membership to IMO with the intention ... to reflect our interests." "131 In fact, this seems true in most cases of the least developed nations that are parties to this Convention.

\footnotetext{
${ }^{128}$ See Marketa Pape, "Briefing: The IMO — for Safe, Secure and Efficient Shipping on Clean Oceans", European Parliamentary Research Service, (February 2016), 6-7, available at http://www.europarl.europa.eu/RegData/etudes/BRIE/2016/577964/EPRS_BRI\%282 016\%29577964_EN.pdf (Last visited July 6 2020).

${ }^{129}$ Id., 6

${ }^{130}$ Interview with Anene Kejela, International Cooperation Expert in Ethiopian Maritime Affairs Authority, June 5, 2017

${ }^{131}$ Mekonnen Abera, Director of Ethiopia Maritime Affairs Authority (EMAA), June 5, 2017
} 
Ethiopia has enacted several domestic maritime legislation, directives and has established EMAA as a sectorial regulator. ${ }^{132}$ In light of these, it is one of the few developing LLS that has relatively longer international maritime engagements. ${ }^{133}$ Despite these efforts, it has been facing challenges in the maritime transport service sector. The following section deals with possible challenges that shipping industries from Ethiopia or other developing LLS may face as consequences of some aspects of the EU maritime policy.

\section{The Main Challenges of Maritime Service Sector in Ethiopia}

\subsection{International maritime transport and logistics service costs}

According to the UNCTAD, developing countries particularly in Africa and Oceania pay on average 40 to 70 percent more for international transport of their imports than developed countries. ${ }^{134}$ The primary victims of the cost must be developing landlocked countries due to, inter alia, huge transit related cost.

Ethiopia spends more than two million USD per a day for transit related cost alone. It expends about 30\% of its GDP for logistics and transit related cost. ${ }^{135}$ In order to reduce this cost and to save time wastages in relation to trade across borders, Ethiopian government has taken measures such as

132 See for example, Maritime Sector Administration Proclamation No. 549/2007 that established EMAA, Multimodal - Transport of Goods Proclamation No. 548/2007, Freight Forwarding and Ship Agency License Issuance. Council of Ministers Regulation No.37/1998, Multi-modal Transport of Goods Proclamation No. $548 / 2007$, Ministry of Transport Directives on Training and Certification of Seafarers No.2/2015, as amended in 2016.

133 There are also several other LLS that are actively involved in the international shipping services such as: Azerbaijan, Bolivia, Kazakhstan, Laos, Luxemburg, Moldova, Mongolia, Paraguay, Slovakia, Switzerland and Turkmenistan. Further detail explanations on LLS participation in the international maritime services are available in, Tuerk, "Forgotten Rights? Landlocked States and the Law of the Sea," 339

${ }^{134}$ United Nations Conference on Trade and Development (UNCTAD), Review of Maritime Transport, UNCTAD Publication, UNCTAD/RMT/2015 (Geneva and New York: 2015), 47, available at: http://unctad.org/en/PublicationsLibrary/rmt2015_en.pdf (Last Visited 2 Aug. 2020).

${ }^{135}$ Interview with Ato Mekonnen Abera, Director, Ethiopia Maritime Affairs Authority, June 5, 2017. 
The EU Maritime Regime and Challenges for Land-locked Developing States... 271

expansion of dry ports ${ }^{136}$ and the introduction of a multimodal transport system. ${ }^{137}$ Yet, Ethiopia preforms worse than Sub-Saharan regional average performance in terms of saving transport time and reducing transport costs for her imports.

Part of the problem, as a study found, is caused due to a high freight rate that importers pay for the carriage of goods through the State's monopolistic shipping lines (ESLSE). ${ }^{138}$ Ato Eyasu Yimam, Commercial Department Director of the ESLSE, noted that the freight rates increment is connected with costs of operation, and stated that ESLSE "substantially focuses on imports to Ethiopia as the country's exports are very [low] and hence there are lots of occasions that [ships] sail [without cargo] relying on cargoes to be imported." 139

In fact, the country's exports are not reserved for the national carrier (ESLSE). This gives exporters opportunity to look for and choose lower freight rates from international shipping markets. All imports to Ethiopia with few exceptions and exemptions, are reserved for the ESLSE, ${ }^{140}$ and this gives the ESLSE not only an opportunity to enjoy monopoly over carriage of the country's imports including fixing freight rates but also a chance to stay alive in the international shipping platform as discussed below.

\footnotetext{
${ }^{136}$ Currently there are seven dry ports in Ethiopia. These are: Mojo, Combolcha, Semera, Mekele, Kality, Diredawa and Gelan.

${ }^{137}$ The multimodal system of transport was introduced by the Multimodal Transport of Goods Proclamation No. 548/2007. See also the 2012 Ethiopian Ministry of Transport Directives on Multimodal Transport of Goods.

138 Tilahun Esmael Kassahun (2014), 'Trade Facilitation in Ethiopia: The Role of WTO Accession in Domestic Reform,' Mizan Law Review, Vol. 8, No. 1:145-189

${ }^{139}$ Interview with Ato Eyasu Yimam, Commercial Department Director of the ESLSE, February 2, 2017.

${ }^{140}$ See the 2008 Ethiopia National Bank (NBE) Directives and the 2012 Ministry of Transport Directives of Multimodal Transport (FOB Directive). In the former directive, NBE set a precondition condition for all commercial importers to use the ESLSE in order to get a letter of credit (LC) any bank in Ethiopia on which almost all importers depend. The later directive prescribes commercial importers that use ESLSE have to buy goods using a FOB term.
} 


\subsection{International competition, escalating port states controls and coastal states power and implications}

In the 1980s and early 1990s, ESL used to provide international shipping services to and from Europe. ${ }^{141}$ But since 1990s, the ESL/ESLSE has stopped direct operation to Europe and shifted to China, Korea, Japan, the Gulf and India, Singapore, South Africa and Indonesia. Under a few circumstances, ESLSE has used vessels chartered from major global carriers like Maersk, ALP and MSC, especially to Turkey and Ukraine. The main reasons pointed out by Eyasu are: high cost of operation, less availability of import cargoes as compared to countries the company shifted to and strict port requirements and controls. He stated that "European ports are so expensive, Suez Canal costs are very high, the EU controls are unreasonably strict and their required standards for a ship are very high."142

Zenebe Asefa, Technical Department Director of ESLSE indicated that, Ethiopia's "ships fulfill basic IMO's safety and environmental standards but EU usually requires more". He noted that "for example the EU requires vessels to use fuel with sulfur content very lower than the IMO requirement which is so expensive. Generally, a small technical fault is sufficient for prohibition of entrance to EU waters or ports particularly when they target your fleet." 143

On the other hand, Captain Getinet Abay, who has served in ESL/ESLSE for more than 20 years as a captain argues that EU's strict PSC or requirements are not main reasons for the ESLSE's shift to the Far East, Middle East or the Indian sub-continent, and he notes that cargo volume and trends are the main factors. ${ }^{144}$

Mekonnnen Abera, director of EMAA, stated that "the main reason for ESLSE's survival in international shipping market is commitment of Ethiopian government thereby offering protection to it through the FOB directives." 145 The FBO directive preserves all commercial imports with few exemptions to the ESLSE. ${ }^{146}$ According to Mekonnen, one of the main potential challenges for Ethiopian shipping industry is tough global competition as the protection could not stay forever. In fact, existing studies

\footnotetext{
${ }^{141}$ Interview with Eyasu Yimam, February 2, 2017

142 ibid

${ }^{143}$ Interview with Zenebe Asefa, Director, Technical Department of the ESLSE, Feb 5, 2017.

${ }^{144}$ Interview with Captain Getnet Abay, July 4, 2017.

${ }^{145}$ Interview with Mekonnen Abera, June 4, 2017.

${ }^{146}$ See the 2008 Ethiopia National Bank Directives and the 2012 Ministry of Transport Directives of Multimodal Transport (FOB Directive)
} 
The EU Maritime Regime and Challenges for Land-locked Developing States... 273

have already shown that such protection had resulted in inefficiency and impact on importers. ${ }^{147}$

According to Captain Getinet, there are global trends that PSC from developed States including the EU's are getting stricter and unaffordable for small landlocked States from time to time on matters related to safety, security and environment. Even though the EU's effective mechanism of implementations of IMO rules (by transposing it to its legislation) can be considered as beneficial for the attainment of international safety, security and environmental protection, some aspects of it could be harmful for developing countries interested in international shipping.

The EU's exercise of port or coastal State jurisdiction that could make maritime trade unaffordable for developing LLS is, inter alia, implemented in three ways: (i) by setting more strict standards than international standards; (ii) implementing international standards ahead of timelines set for the implementations of the rules; and (iii) serving as a major driving force for timely tightening of the IMO standards.

To give a particular example for each case, let's take the IMO rules under MARPOL Convention, revised Annex VI, and the most recent EU directive 2016/802/EU (Sulfur directive). The current IMO regulation limit for sulfur content of fuel oil used by ships is $3.50 \% \mathrm{~m} / \mathrm{m}^{148}$ whereas the sulfur limit for ships at berth in the EU ports is $0.1 \% \mathrm{~m} / \mathrm{m}$ and in "EU's territorial seas, exclusive economic zones and pollution control zones falling outside $\mathrm{SO}_{\mathrm{x}}$ Emission Control Areas for passenger ships operating on regular services to or from any Union port" is $1.5 \% \mathrm{~m} / \mathrm{m} .{ }^{149}$

The second situation is when the EU implements international rules ahead of the timeline set therein. For example, EU declared phasing out of a single hull tanker ahead of the IMO deadline. The deadline for $3.50 \%$ sulfur content limit in the case of the IMO was January 1, 2020 whereas the EU's deadline was 18 June 2014. Moreover, the IMO was conducting preparatory works to regulate green gas emission cap from ships while the EU had already adopted a regulation in $2015 .{ }^{150}$ This shows that the EU, in the IMO regulatory system, is not only reactive but also proactive.

\footnotetext{
${ }^{147}$ Tilahun Esmael Kassahun, 'Trade Facilitation in Ethiopia: The Role of WTO Accession in Domestic Reform', supra note 138, p. 171.

148 See revised MARPOL Annex VI, regulation 14 (1)

${ }^{149}$ Article 7(1) and 6(5) of the EU sulfur directive 2016/802/EU respectively. Note that: price of fuel oil with a low sulfur content is so expensive.

150 See the EU Regulation 2015/757/EU
} 
It is thus submitted that escalating exercises of port or coastal States jurisdictional power, inter alia, the EU's trends of port or coastal State jurisdictional exercise or control have negative implications for developing LLS. Particularly, the EU maritime measures such as: setting more strict standards than international standards, implementing the international standards ahead of the timeline set therein, and influencing the IMO to elevate international standards are capable of making participation of developing LLS in the international shipping service unaffordable. For instance, it has already become unaffordable for Ethiopian shipping industry to undertake direct operation of international shipping to and from EU.

\section{Conclusion}

As discussed in the preceding sections, the EU maritime policy including its port State control regime could make international maritime trade through its waters very difficult for developing LLS. Particularly, the EU's regulatory actions (such as setting more strict standards than international standards to foreign ships operating in its waters or visiting its ports, and implementing the international standards ahead of the timelines set for implementation) may, in the absence of special treatment schemes, hamper the interest of the developing LLS to trade through the EU waters. Developing LLS which are already overwhelmed by economic and transit related problems could not afford the escalating standards and do not have bargaining position comparable with developed or coastal States. And ultimately, this may lead to the withdrawal of the developing LLS from shipping business through the EU waters as it is evident from Ethiopia's experience

It is argued that increasing EU's port State controls may give rise to more port States controls from other major global port or coastal States. If the EU continues its excessive port or coastal State jurisdictional schemes by setting its own standards to foreign vessles, there is a high probability that other major port or coastal States may exercise countermeasures in their capacity as port States or regional integrations for port State control. This seems to be likely because international maritime trade is, inter alia, determined by the bargaining position of the actors. The bargaining position of States is mostly determined by factors such as economic, diplomatic and geo-political position. But developing LLS cannot be in these positions because they do not have ports or sea coasts and have the lowest bargaining position in the international maritime field. This, in effect, might in absence of preferential or differential treatment, frustrate the developing LLS and affect their engagement in international maritime transport service. This ultimately may result in complete withdrawal of these States from the international maritime arena. 
The EU Maritime Regime and Challenges for Land-locked Developing States... 275

As highlighted above, the EU, by using its coordinated power, experience in maritime field and expertise has been influencing the IMO to progressively raise safety, security and environmental protection standards. In the absence of a preferential treatment, this could make the international shipping standards unaffordable to developing LLS. EU regulations, inter alia, regulations on freedom to provide service and coordinated action to safeguard free access of ocean cargos are designed to apply on any third country including developing LLS. The regulations may subject developing LLS that (due to their special needs) reserve cargoes to national shipping industry or otherwise protect the industry. Due to their low competitive capacity, shipping industries from developing LLS would not be threat to EU shipping companies in terms of market size or the number of merchant vessel fleet they operate. It is thus submitted that the EU should revisit its regulations by targeting at the third competitive States or devise some kind of special or differential treatment scheme to developing LLS.

It is suggested that recognizing the inherent problems of developing LLS and the economic interest of these States in the maritime service sector, both international maritime regulations and EU maritime policy and regulations should have differential treatment schemes for the developing LLS. Particularly, maritime environmental protection related regulations should consider the fact that these States are severely affected by the global challenges caused by environmental degradation such as climate change, while their contribution toward pollution and industrial emissions is minimal. The Principle of Common but Differentiated Responsibilities thus envisages differential treatment scheme for these States.

Accordingly, the regulation to safeguard free access of ocean cargos should provide for exceptional clause that benefits shipping services from developing LLS. By according incentive schemes for these States in the maritime field, it is possible to bring about global sustainable development given the economic importance of seas and oceans. It is only in the context of inclusive global sustainable development that LLS can come out of the poverty and underdevelopment trap which clearly worsens overexploitation of the natural resources to the detriment of the global commons and environmental sustainability. 